\title{
RULES FOR THE ASTIN SECTION OF THE INTERNATIONAL ACTUARIAL ASSOCIATION
}

I. The section for actuarial studies in non-life insurance (ASTIN), formed according to the rules of the International Actuarial Association has as its object the promotion of actuarial research in general insurance. The ASTIN section will establish contact between actuaries, groups of actuaries and other suitably qualified persons interested in that field.

2. There will be three classes of members, as follows:

Ordinary Members, being members of the International Actuarial Association who indicate their desire to join the section and register accordingly.

Special Members, being persons of qualifications who may be elected to membership of the section on the recommendation of at least two ordinary members.

Corporate Members, being institutions of any appropriate type who are interested in the affairs of ASTIN and contribute towards its expenses and who may be elected to membership of the section on the recommendation of at least two ordinary members.

Any member may resign at any time by giving due notice in writing.

3. The affairs of the section shall be managed by a Committee of not more than eleven members. One or two of them shall be appointed by the International Actuarial Association. The remaining members shall be elected by and from amongst the ordinary members every four years. The Committee shall appoint from among themselves a Chairman, a Secretary, a Treasurer and an Editor.

4. The section will, from time to time, publish papers on topics related to its objects and also publish a bulletin containing notes of general interest to members.

5. The section will hold conferences as determined by its Committee, such conferences to be normally held not less frequently than once every four years. The conference will be open to ordinary 
and special members of the section. Should the conference be held concurrently with an International Actuarial Congress, the conference will be open to all members of that Congress. The Committee may invite other suitably qualified persons to take part in such conferences.

6. Membership fees will be determined at the conferences of members by a simple majority of the ordinary members present.

7. Change of rules and election of Committee members shall be determined by a simple majority of the ordinary members present at a general meeting. Recommendations for alterations to the rules or for election of Committee members shall reach the Secretary at least three months before the date of voting. No change of rules shall take effect until approval has been given by the International Actuarial Association. 